\title{
GRAMMATICALIZATION THROUGH LANGUAGE CONTACT: THE PERIPHRASTIC PASSIVE IN CHONTAL MAYAN
}

\author{
Brad Montgomery-Anderson \\ Northeastern State University, Tahlequah, OK
}

\begin{abstract}
This paper is a discussion of a periphrastic passive in Chontal Mayan, a construction I claim is a result of contact with Spanish. The purpose of this paper is to describe this passive and to compare and contrast its function with that of the more common morphological passive. This paper will explore issues of grammaticalization as well as typological studies of the passive to put these hypotheses into a proper diachronic and synchronic perspective. A tentative proposal is drawn up for the functions of the Chontal passive and passive-like constructions, as well as indications for further research to better establish these claims.
\end{abstract}

\section{Introduction}

Periphrastic passive constructions involve auxiliation, a diachronic process whereby a lexical verb becomes bleached of its semantic meaning and acquires a grammatical function. This paper is an exploration of a case of auxiliation through language contact in Chontal Mayan. In the case of Chontal, contact with Spanish seems to have caused a native Chontal verb $x$ - 'to go' to acquire a new function as an auxiliary that, when combined with a participle, functions as a passive construction. In this paper I claim that this new periphrastic passive is based on the homophony of the preterit forms of the Spanish verbs 'to go' and 'to be.'

The literature on language contact does not contain many examples of the diffusibilty of passives. One example of contact-induced change in the meaning of a passive comes from Mandarin Chinese. This 'adversative passive' historically has carried with it an unfortunate or pejorative sense, but its use with a neutral sense has increased under influence from Indo-European languages (Li \& Thompson 1981). Blake (2001) provides further examples where European influence has expanded the use of existing passives in Asian languages. He also mentions that the influence of European languages has been responsible for greater use of periphrastic verbs globally; the example he offers is a periphrastic verb construction in Pipil that is calqued on Spanish (Harris \& Campbell 1995:149, cited in Blake 2001).

The passive voice is a construction in which more attention is focused on the subject/agent and less on the object/patient. The Mayan languages of Mexico and Central America all have a passive 
construction; in fact, many of them have more than one passive to convey different shades of meaning (e.g. aspect or degree of control on the part of the agent). Mayan languages prototypically mark any changes in transitivity with a verbal affix that marks the new derivation. (1) is an example of a typical active transitive in Kaqchikel, an Eastern Mayan language of Guatemala.

$$
\begin{array}{lll}
x \text {-e-ki-chäp } & a k^{\prime} w a l-a & \text { ri ixoq-i' } \\
\text { CMP-B3.PL-A3.PL-grab } & \text { child-PL } & \text { DET woman-PL }
\end{array}
$$

'The women grab the children.' (Matzar \& Rodriguez 1997:369) ${ }^{1}$

The corresponding passive is the following:

$$
\begin{array}{lll}
x \text {-e-chap } & a k^{\prime} w a l-a & \left(k-u m a \quad \text { ri ixoq- } i{ }^{\prime}\right) \\
\text { CMP-B3.PL-grab.PSV } & \text { child-PL } & \text { (A3.PL-RN DET woman-PL) }
\end{array}
$$

'The children are grabbed (by the women).'

Languages in the Mamean branch of the Mayan family have a morphological passive as well. The Mam sentences below demonstrate that 1) the lack of an ergative marker indicates the verb is now intransitive, 2) 'horse', as the sole non-peripheral NP, is now the subject, 3) 'brother' is demoted by being placed in a peripheral prepositional phrase and 4), the verb is marked with a special affix.

Mam (Pérez \& Jiménez 1997: 333)

$$
\begin{array}{llll}
x i & t-j k^{\prime} u^{\prime}-n & w \text {-iitz'in-e' cheej } \\
\text { DIR } & \text { A3-pull-ADJ } & \text { A3-brother-ENC horse }
\end{array}
$$

'My younger brother pulled the horse.'

$$
\begin{aligned}
& j k^{\prime} \text {-eet cheej } \quad t \text {-u'n } \quad \text { w-iitz'in-e' } \\
& \text { pull-PSV horse PREP A3-brother-ENC } \\
& \text { 'The horse was pulled by my younger brother.' }
\end{aligned}
$$

Such a valency-adjusting affix is present in all branches of the Mayan family. Most of the languages of Guatemala are in the Eastern branch; another branch, Huastecan, is spoken in the states of Veracruz and San Luis Potosí, while a third branch, Yucatecan, is found on the Yucatan peninsula. The fourth branch of the Mayan family, Western Mayan, is located in the Mexican states of Chiapas and Tabasco as well as western Guatemala. Chontal is part of this Western grouping and is spoken in the state of Tabasco; the dialect under consideration is spoken in the municipio of Nacajuca north of the state capital of Villahermosa. Like other Mayan languages it is an ergative language that uses absolutive markers for pronominal intransitive subjects and transitive objects and ergative markers for pronominal transitive subjects and possessors. ${ }^{2}$ An example of this phenomenon in Chontal is in

${ }^{1}$ I have slightly altered the original abbreviations for the other Mayan languages so that, when possible, they match those used for Chontal.

${ }^{2}$ I use the following abbreviations: 1=first-person marker, $2=$ second-person marker, $3=$ third-person marker; $\mathrm{A}=$ Set $\mathrm{A}$ (ergative), $\mathrm{ADJ}=$ adjective derivational suffix, $\mathrm{APL}=$ applicative, $\mathrm{B}=\mathrm{Set} \mathrm{B}$ (absolutive), $\mathrm{CMP}=$ completive, $\mathrm{DET}=$ determiner, $\mathrm{DRV}=$ verbal derivational suffix, $\mathrm{MAS}=\mathrm{Masculine}$ classifier, $\mathrm{INC}=$ incompletive, $\quad \mathrm{NEG}=$ negative, $\quad \mathrm{PL}=$ plural, $\quad \mathrm{PSV}=$ passive, $\quad \mathrm{PL}=$ plural, $\quad \mathrm{PREP}=\mathrm{preposition}$, $\mathrm{PRN}=$ independent pronoun, $\mathrm{PST}=$ past proclitic, $\mathrm{RFL}=$ reflexive, $\mathrm{RN}=$ relational noun. In the writing system 
(5) and (6); good overviews of these features for Mayan languages are in Kaufman (1990) and England (2001). In these examples the completive is expressed with a null morpheme.

(5) 'a $\quad x-\varnothing-e t$

PST go-CMP-B2

'You went up.'

(6) kä-jätz'-Ø-et

A1-hit-CMP-B2

'I hit you.'

Chontal also displays split ergativity that is sensitive to aspect as well as negation. In the incompletive the Set A marker references the intransitive argument, while in the completive a Set B marker references it:

(7) $\quad k \ddot{a}-x-e$

A1-go-INC

'I go.'

$$
\begin{array}{ll}
\text { 'a } & x \text {-Ø-on } \\
\text { PST } & \text { go-CMP-B1 }
\end{array}
$$

'I went.'

Verbs have one or two arguments marked on the verb. Like other Mayan languages, Chontal is sensitive to the distinction between transitive and intransitive verbs as well as root and derived verbs. Root verbs (i.e verbs that are not derived from another word) have distinct suffixes to reflect the difference in valency. Thus a root intransitive adds a suffix $-o$ or $-e$ to express the incompletive:

$$
\begin{aligned}
& \text { 'u-x-e } \\
& \text { A3-go-INC } \\
& \text { 'He goes.' }
\end{aligned}
$$

A root transitive indicates the incompletive with $-e$ '. The Set B third person marker is a null morpheme.

$$
\begin{aligned}
& \text { 'u-jätz'-e'-Ø } \\
& \text { A3-hit-INC-B3 } \\
& \text { 'He hits it.' }
\end{aligned}
$$

Derived verbs do not take special markers to distinguish transitive and intransitive. The most common suffixes for derived verbs are -an, -än, and -en:

used for Chontal, $[\mathrm{x}]$ is an alveopalatal fricative, ['] represents either a glottal stop or glottalization of a stop or affricate, and [ä] repesents a high central vowel. All other letters in the writing system used for Chontal have the same value as in Spanish. 
(11)

'u-pok'm-an

A3-become fat-INC

'He becomes fat.'

(12)

'u-pal-än- $\emptyset$

A3-whittle-INC-B3

'He whittles it.'

As exemplified in (13), intransitive verbs that are positive incompletive take the ergative markers:
$\boldsymbol{k} \ddot{a}-w \ddot{a} y-e$
A1-sleep-INC
'I'm sleeping.'

Most of the Mayan languages have a productive antipassive, and all have at least one kind of passive. These voice changes are typically morphological in nature in that they are created by the addition of an affix. ${ }^{3}$ In Chontal the morphological passive is a frequently-found construction; it is expressed with a $-k$ for root verbs and an -int for derived verbs. Active/passive pairs are in (14-15) and (16-17).

Active:

'u-chon-e'- we'e

A3-sell-INC-B3 meat

'He is selling meat.'

Passive for root verb:

'u-chon-k-an we'e

A3-sell-PSV-INC meat

'Meat is sold.'

Passive for derived verb:

(16) 'a pop-int-i- $\emptyset$

PST roast-PSV-CMP-B3

'It was roasted'/'Lo asaron. ${ }^{4}$

${ }^{3}$ Siewierska (1984:126) lists Tzeltal (also from the Western Mayan branch) as having a periphrastic passive. She reports that this passive is formed from the verb receive/get. Because it is transitive, one can see how this verb could grammaticalize (with or without Spanish language contact) into an auxiliary for a periphrastic passive and is thus fundamentally different from the Chontal construction involving intransitive $x$-. Good overviews of voice in Mayan languages are in Aissen (1990) and Dayley (1990).

${ }^{4}$ I give the original Spanish translations provided by my sources when theses translations are relevant. The English translations are my own. 
(17)

k'os-b-int-i- $\boldsymbol{\varnothing}$

bring-APL-PSV-CMP-B3

'It was brought to him'/ 'le trajeron.'

Unlike some Mayan languages, however, this is the only morphological passive; i.e. there is no distinction between a passive where the demoted agent is relegated to an oblique phrase and the absolute passive where the agent is deleted. Thus there is always the option of indicating the agent, as shown in (18).

'u-k'ux-k-an (k'a kande)

A3-eat-PSV-INC (PREP 1PRN)

'It is eaten (by me).'

\section{Uses of the Chontal Periphrastic Passive}

During field work in Mexico for the Project for the Documentation of the Languages of Mesoamerica I came across an example of the periphrastic passive construction that is the topic of this paper. The example was in Las Doce Verdades, a bilingual Spanish-Chontal book of short stories written by Isaías Hernández Isidro. Note in the following sentence the passive is expressed periphrastically with the verb $x$ - 'to go' and a participle:

$\begin{array}{llllll}n-u \text {-ch'ich'é } & x-i-\emptyset & \text { 'uch'-u } & k^{\prime} a & n i & \text { sutz'-baläm } \\ \text { DET-A3-blood } & \text { go-CMP-B3 } & \text { drink-ADJ } & \text { PREP } & \text { DET } & \text { bat-jaguar }\end{array}$

'His blood was/had been drunk by the bat-jaguar.'/ 'Su sangre fue bebida por el sutz'balam.' (Hernández 1997:34)

In Chontal adjectives are derived from verbs by adding a copy vowel as a suffix; in this case, ' $u c h$ ' 'to drink' becomes ' $u c h$ ' $u$ 'drunk.' In a different story in the same book there is another example:

$$
\begin{array}{lllll}
x-i-\emptyset & b u k^{\prime}-u & k ' a & n i & p a^{\prime}-o ' \\
\text { go-CMP-B3 } & \text { swallow-ADJ } & \text { PREP } & \text { DET } & \text { popal-PL } \\
\text { 'He was swallowed up by the marshes'/ 'Fue tragado por los popales.' } \\
\text { (Hernández 1997:61) }
\end{array}
$$

The author translates into Spanish these Chontal sentences with a passive construction fue + adjectival participle. In Chontal, the tense-carrying verb $x$-is followed by the derived adjectival form of the transitive verb, a construction similar to the periphrastic passives found in both English and Spanish, both of which use 'to be' as the auxiliary verb.

A careful search of the literature revealed that the only discussion of this construction is a passing mention in Knowles (1984:163). Significantly, the Chontal she described over 25 years ago is of a variety of the language that is fairly different from that of my consultant. She describes this construction as an agentless, or impersonal, expression; her example is in (21). 


$$
\begin{array}{ll}
\text { 'a } \quad x-i-\emptyset & k ' u x-u \\
\text { PST go-CMP-B3 } & \text { eat-ADJ } \\
\text { 'It is eaten (by me).' }
\end{array}
$$

As Isaías Hernández Isidro was also my language consultant that same summer, I had the opportunity to ask him about the acceptability of this construction in other environments. The periphrastic passive was also productive in other persons besides the third person; Isaías used both the morphological and periphrastic passive to translate 'you were kissed by the girl' ('fuiste besado por la mujer'):

morphological:

$$
\begin{array}{llll}
\text { 'ane } & t z^{\prime} u t z^{\prime}-k-\emptyset \text {-et } & k^{\prime} a & \text { 'ixok } \\
\text { 2PRN } & \text { kiss-PSV-CMP-B2 } & \text { PREP } & \text { woman }
\end{array}
$$

$\begin{array}{llll}x-\emptyset \text {-et } & t z^{\prime} u t z t^{\prime}-u & k^{\prime} a & n \text {-ixok } \\ \text { go-CMP-B2 } & \text { kiss-ADJ } & \text { PREP } & \text { DET-woman }\end{array}$

In both of the examples the oblique agent is optional. Unlike the construction described by Knowles, the agent is allowed.

In the previous examples $x$ - has been used in the completive. If the incompletive is used, the result is a future passive. In such a sentence 'go' serves two grammatical functions; i.e. future tense and passive voice:

$$
\begin{array}{ll}
\text { 'a-x-e } & t z^{\prime} u t z '-u \\
\text { A2-go-INC } & \text { kiss-ADJ }
\end{array}
$$

'You will be kissed.' /‘Serás besado.' or 'Te besarán.'

As discussed in the following section, the periphrastic passive probably developed out of contact with Spanish.

\section{Auxiliation through language contact. Spanish Passive}

In Chontal this periphrastic passive exists alongside the morphological passive. While syntactic constructions have a diachronic tendency to coalesce and fuse together, there is another tendency for periphrastic constructions to replace older morphological constructions (Hopper \& Traugott 1990:9). This process of renewal appears to be happening in Chontal. The verb 'to go' is a semantically general verb that, along with other verbs like 'to be' and 'to have', cross-linguistically display a tendency towards grammaticalization. Heine \& Kuteva list nine sources of passive grammaticalization, none of which is the verb 'to go' (2002:333). Siewierska lists the most common auxiliaries for periphrastic passives as the verbs 'to be' and 'to become', but she does state that 'to go' is used in a few Indo-Aryan languages as well as in Gaelic and Italian (1984:126).

${ }^{5}$ The only other difference is that the oblique agent in the periphrastic passive is definite. It would be worthwhile to investigate further to see if definiteness plays a role in selection of either the morphological or periphrastic passive. It is possible that the consultant simply added this detail and that it has no bearing on the passive. 
In Chontal the lexical verb 'to go' has already been grammaticalized to express the future tense/aspect:

$$
\begin{aligned}
& k \ddot{a}-x-e \quad k \ddot{a} \text {-jätz'-e'-et } \\
& \text { A1-go-INC A1-hit-INC-B2 } \\
& \text { 'I'm going to hit you.' }
\end{aligned}
$$

From this construction one can see how Chontal could have grammaticalized, on its own, the immediate future. Like a corresponding Spanish or English construction, the above sentence could imply either futurity or movement. A sentence where movement cannot be implied is necessary to show that 'go' can only express futurity (e.g. 'I'm going to stay here all day'), Although this construction also could be a result of contact from Spanish; it is more likely, given the widespread use of this grammaticalization pathway (Heine \& Kuteva 2002:161) that this construction developed on its own. ${ }^{6}$

However, it is difficult to see Chontal developing the $x$-periphrastic passive on its own because of the lack of constructions that would be subject to reanalysis. Siewierska notes that grammaticalized auxiliaries often carry an allusion to their former lexical meaning (1984:128). A sentence such as $x i$ ' $u c h$ ' $u$ 'It was drunk' has no meaning if $x$ - is interpreted as movement; i.e. * 'it went drunk.' It seems more likely that such a use of $x$ - is a calque on the Spanish periphrastic passive. To create a passive Spanish uses the auxiliary verbs ser or estar, both of which mean 'to be'; the former is used for permanent states and the second for more temporally-based states or conditions. In Chontal a similar construction is found with a defective verb that often acts more like a particle:

$$
\begin{array}{ll}
\text { 'ajn-i- } \emptyset & \text { chop-o } \\
\text { be-CMP-B3 } & \text { throw-ADJ } \\
\text { 'It was thrown.'/'Estuvo tirado.' }
\end{array}
$$

tus- $u \quad y a$ 'an
organize-ADJ be/there is
'It was organized.'/ 'Fue acomodado.'

Keller \& Luciano (1997:455) state that when a participle is the nucleus of the sentence, it is usually combined with the copulas 'an or 'ayan. They point out that such constructions are only available in the third person:

$$
\begin{array}{ll}
\text { juch'-u an } & \text { 'It is ground.'/‘Está molido.' } \\
\text { chon-o an } & \text { 'It is sold.'/'Está vendido.' } \\
\text { jutz'-u an } & \text { 'It is washed.'/‘Está lavado.' }
\end{array}
$$

These same participles can refer to first or second person using absolutive markers in a stative construction. In such a construction no copula appears and the absolutive marker is attached directly to the participle:

${ }^{6}$ Because of the high degree of bilingualism in the Chontalpa, it is possible that the Spanish construction has reinforced the Chontal construction. Heine \& Kuteva report this grammaticalization for the Mayan language Tzotzil (2002:162). 
k'ätäl-on 'I am asked for.'/ 'Estoy solicitada.'

In both constructions no mention of the agent is possible. Due to their irregularity, the ya'an/ajn verbs are poor candidates for an auxiliary verb; i.e. an auxiliary to carry all the person and aspect specifications that the deverbalized participle can no longer specify.

In Spanish the past tense of ser is phonetically identical to the past tense of ir 'to go.' Ser, like estar, can be an auxiliary for passive constructions:

El agresor fue detenido por la policía ～(de Bruyne 1996:463)

'The attacker was arrested by the police.'

Javier es un hombre acostumbrado a ser servido por mujeres

'Javier is a man used to being waited on by women.'

If the Chontal passive is indeed a calque, the calque is based on a reanalysis of the past tense of Spanish ser as the past tense of ir. Chontal $x$ - has regular inflection for all persons and aspects and is a good base to carry this information as an auxiliary verb. Aikhenvald \& Dixon (2006) call this kind of change 'grammatical accommodation'; i.e. reinterpretation as a result of look-alike forms.

A possible way to test this hypothesis would be 1) to see if the periphrastic is used more in the past tense; i.e. if it is the more frequent, unmarked form and, 2) if restrictions that apply to the auxiliary use of ser in Spanish have some kind of reflex in the use of Chontal $x$ - as an auxiliary. De Bruyne points out a restriction on the Spanish use in that "the ser + past participle form of the passive implies the involvement of an agent, even if this is not expressed; when no specific agent can be involved, it is preferable to use the reflexive..." (1996:462). If Chontal were shown to have a similar preference in its periphrastic construction, we could take this preference as supporting evidence for passive $x$ - as a loan calque from Spanish. In fact, Spanish does have various constructions that are used to express degrees of involvement by an agent. For example, Spanish has a construction that uses the reflexive to express a passive or mediopassive meaning. If there is no agent involved or implied, this passive reflexive is the preferred form. When asked to translate a sentence such as 'la puerta se abrió', Isaías used a reflexive Chontal form that is possibly also a calque of the Spanish:
$n-u-t i$
'otot 'u-jäb-i- $\emptyset$
' $u-b a$
DET-A3-mouth
house A3-open-CMP-B3
A3-RFL
'The door opened.'

When asked to translate the present perfect 'la puerta se ha abierto', Isaías used the 'to be' copula with an adjectival form of the verb:

$$
\begin{aligned}
& n-u-t i \text { 'otot ya'an jäb-a } \\
& \text { DET-A3-mouth house there.is open-ADJ } \\
& \text { 'The door has been opened.' }
\end{aligned}
$$

This construction as well could be the equivalent of Spanish estar + past participle. De Bruyne describes this Spanish construction as a passive that denotes a resultant state; significantly, the estar 
construction differs from the ser construction in that 'the estar-passive only admits an agentive phrase when the agent is necessarily involved in the "resultant state"...' (1996:464).

In Chontal it seems that the periphrastic passive with $x$-is preferred when an agent is clearly involved. Isaías gives the following translation for the Spanish 'la puerta fue abierta por el hombre'.

$\begin{array}{llllll}n-u-t i & \text { 'otot } & x-i-\emptyset & j a ̈ b-a & k^{\prime} a & y \text { inik } \\ \text { DET-A3-mouth } & \text { house } & \text { go-CMP-B3 } & \text { open-ADJ } & \text { PREP } & \text { man }\end{array}$

'The door was opened by the man.'

This distinction is made clear by the speaker. When translating the following example, he states that 'no one is to blame' ('no hay un culpable'):

$$
\begin{array}{ll}
\text { ni basu } & t^{\prime} o x-k-i-\emptyset \\
\text { DET vase } & \text { break-PSV-CMP-B3 }
\end{array}
$$

'The vase broke.' /'El vaso se rompió.' or 'El vaso se ha roto.'

Note that in the above example the morphological passive is used. When this is compared to its periphrastic counterpart, Isaías comments that 'here we must find out who broke it' ('aquí hay que investigar quien lo rompió'):

$$
\begin{array}{llll}
\text { ni basu } & x-i-\varnothing & t^{\prime} o x-o & \left(k^{\prime} a c h ' o k\right) \\
\text { DET vase } & \text { go-CMP-B3 } & \text { break-ADJ } & \text { (PREP child) }
\end{array}
$$

'The vase was broken by the child.'/'El vaso fue roto por el niño.'

It should be pointed out that certain intransitive verbs carry an inherent mediopassive meaning:

$$
\begin{array}{lcc}
n i \quad \text { vejika } \quad \text { a } & \text { top'-i- } \emptyset \\
\text { DET balloon } \quad \text { PST } & \text { burst-CMP-B3 } \\
\text { 'The balloon burst.' /'El globo se reventó.' }
\end{array}
$$

Interestingly, some of these verbs accept the oblique phrase expressing an agent. Isaías reports for the above that 'no one is to blame'. An agent can be introduced, however, without any change in the verbal morphology:

$$
\text { ni vejika 'atop'i k'a ch'ok }
$$

'The balloon was burst by the child.'/‘El globo se reventó por el niño.'

This sentence could be awkwardly translated as 'The balloon was broken through the fault of the child/ because of the child' as this preposition is connected to the word for 'reason' and probably developed from a relational noun; i.e. a possessed noun that acts as a preposition (its.reason $=$ because). This is the common pattern in most Mayan languages. 


\section{Comparative Perspectives}

It is useful to take into consideration comparative data to explore the possibility that the periphrastic passive evolved through contact. In his study of passive grammaticalization, Haspelmath (1990:28-9) drew 80 languages from the Gramcats sample. Of these, he found that only 31 had a passive. These 31 had 39 grammatical morphemes that he divided in the following manner:

\begin{tabular}{|l|c|}
\hline ADDITIONAL STEM AFFIX & 25 \\
\hline AUXILIARY VERB + PARTICIPLE & 6 \\
\hline PARTICLE & 1 \\
\hline EXTRAINFLECTIONAL AFFIX & 3 \\
\hline DIFFERENTIAL SUBJECT PERSON MARKERS & 2 \\
\hline ALTERNATE STEM AFFIX & 1 \\
\hline
\end{tabular}

For this randomly generated sample, Haspelmath states that all the auxiliary verb passives occurred in the Indo-European languages and concludes that "although this expression type is certainly not confined to Indo-European, the distribution of the Gramcats sample confirms Dryer's (1982:55) observation that the use of the copula plus an adjectival in passive clauses is rare outside IndoEuropean. In most languages, the passive is formed by adding a passive affix to the verb."' Thus two pieces of comparative evidence indicate that the periphrastic passive has come about through language contact: 1) None of the thirty Mayan languages is known to have such a passive and 2) this type of passive is found mainly in the Indo-European family (i.e. Spanish) and is rare outside this family.

What would be the functional purpose of such a syntactic borrowing? Benveniste (1967:85) describes changes in categories to be either innovating or conservative. Innovating changes are what he calls the loss or innovation of grammatical functions. An example of this would be the loss of the dual grammatical category in most Indo-European languages. Conservative changes (or mutations, as Benveniste terms them), on the other hand, replace a grammatical category expressed through a morpheme with a new periphrastic construction. In other words, the form changes, but the grammatical function itself remains.

The Chontal periphrastic passive is of the second type, as it exists alongside a quite productive morphological passive. Thus the sentence 'The woman was woken up by her child' can be rendered in two ways:

Morphological: Ni 'ixik pis-int-i (k'a 'uch'ok)

Periphrastic: $\quad$ Ni 'ixik xi p'ix-i (k'a 'uch'ok)

This observation of the coexistence of the two forms fits with what we know of grammaticalization from other languages. Hopper \& Traugott point out that grammaticalization typically does not result in the filling of a functional gap, but rather competes with existing functions (1993:125). At this point the Chontal periphrastic passive appears much less frequently than the morphological passive. Its function frequently seems to be similar to that of the traditional passive construction.

At the same time, one suspects that the two constructions are not equal, but that one is marked and the other unmarked. The marked construction would have more restricted or specialized functions. In most cases the two constructions were equally acceptable, although Isaías often gave 
the morphological passive first. When asked to extract the underlying patient for questioning, he clearly preferred the morphological passive:

$$
\begin{array}{llll}
\text { kune } \quad \text { 'a } & \text { k'ech- } k-i-\emptyset & \text { (k'a ni yinik)? } \\
\text { who PST } & \text { grab-PSV-CMP-B3 } & \text { (PREP DET man) } \\
\text { 'Who was grabbed by the man?'/'Quien fue agarrado por el hombre?' }
\end{array}
$$

Isaías stated that the corresponding periphrastic passive 'sounded ugly.'

$$
\text { *kune 'axi k'eche (k'a ni yinik) }
$$

He did note, however, that the addition of an oblique phrase made it sound better but still incorrect. The unacceptability of such a construction could be due to kune being used as an interrogative for both patients and agents. ${ }^{7}$

So far I have found one situation where the periphrastic construction is preferred over the morphological passive. When the demoted agent is questioned, the periphrastic passive is the only acceptable form:

\section{*k'a kune 'a'uch'ki ni ch'ich'?}

Interpretation sought: By whom was the blood drunk?/ por quien fue bebido la sangre?

$\begin{array}{lllll}k^{\prime} a k \text { kune } & x-i-\varnothing & \text { 'uch'-u } & n i & \text { ch'ich'? }^{\prime} \\ \text { PREP who } & \text { go-CMP-B3 } & \text { drink-ADJ } & \text { DET } & \text { blood }\end{array}$

'By whom was the blood drunk?'/ 'Por quien fue bebido la sangre?'

This restriction is intriguing, because Chontal is one of the few Mayan languages with no productive antipassive. The antipassive is used in other Mayan languages to extract agents for questioning, topicalization or relativization. The periphrastic passive could then have the function of taking up where the obsolete antipassive left off. Recall the second example from Las doce verdades:

$$
\begin{array}{lllll}
x-i-\emptyset & b^{\prime} u k^{\prime}-u & k^{\prime} a & n i & p a^{\prime}-o ' \\
\text { go-CMP-B3 } & \text { swallow-ADJ } & \text { PREP } & \text { DET } & \text { popal-PL }
\end{array}
$$

'He was swallowed by the marshes.'/ 'Fue tragado por los popales.'

Isaías translates this sentence with the Spanish periphrastic passive, the reflexive passive being unavailable due to the presence of the oblique phrase. It is clear from the discourse context why the passive is preferred: the object of the immediately preceding clause is now the subject.

$$
\begin{aligned}
& \text { mach 'u-pojl-i-Ø-jo' } \quad x-i-\varnothing \quad \text { buk'-u } \quad \text { k'a ni pa'-o' } \\
& \text { NEG A3-find-CMP-B3-PL go-CMP-B3 swallow-ADJ PREP DET popal-PL }
\end{aligned}
$$

'They did not find him; he was swallowed by the marshes.'

\footnotetext{
${ }^{7}$ The periphrastic passive is acceptable in a sentence where there is an oblique phrase with a proper noun: kune
} xi kunu k'ajbal. 'Who was hit by Valdomero'/‘Quien fue pegado por Valdomero?' 
The subject of the passive, the lost fisherman, is the object of the first clause; the passive is used in the following clause to keep him in the foreground. Changing a transitive verb into an intransitive verb is a means of foregrounding the important information. In his study of preferred argument structure, Du Bois points out that the choice of an intransitive or transitive verb is a means of managing information flow (1987:830). If the clause were in the active voice, there would be unnecessary emphasis on the marshes and we would perhaps lose track of the topic that matters (i.e. the lost fisherman). ${ }^{8}$ A few sentences down we learn that the fisherman is healed, which in Spanish is rendered as fue sanado, with no oblique phrase:

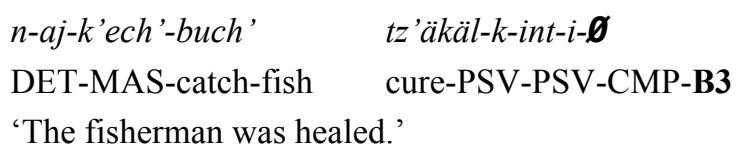

Significantly, the Spanish translation of the morphological passive is typically a sentence with an active verb in the third person. While this Spanish construction is not a true passive, it is functionally similar to this construction; its chief purpose is to foreground the object and background the subject. De Bruyne (1996: 461) lists it as one of the seven means of conveying the 'passive idea' in Spanish. This pseudo-passive is found in many European languages when one wishes to background an unknown or unimportant agent. In such cases it is possible to use a generic, non-referential they. For example, in English one may use 'they say' to mean 'it is said', while in Russian we find меня зовут 'they call me' to mean 'I am called' (i.e. 'My name is').

There is some evidence that this use of the generic plural third person is being grammaticalized in another Mayan language, the Kaqchikel language (Eastern Mayan) of Guatemala. Recall the pair of standard Kaqchikel active-passive sentences discussed at the beginning of this paper:

$$
\begin{array}{lll}
x \text {-e-ki-chäp } & a k^{\prime} w a l-a & \text { ri ixoq-i' } \\
\text { CMP-B3.PL-A3.PL-grab } & \text { child-PL } & \text { DET woman-PL }
\end{array}
$$

'The women grab the children.'

$$
\begin{array}{llll}
x \text {-e-chap } & a k^{\prime} \text { wal-a' } & (k-u m a & \text { ri ixoq-i') } \\
\text { CMP-B3.PL-grab.PSV } & \text { child-PL } & \text { (A3.PL-RN } & \text { DET woman-PL) }
\end{array}
$$

'The children are grabbed (by the women).'

As we have seen, this way of forming the passive is typical of Mayan languages. Broadwell \& Duncan describe a new way of producing the passive that involves grammaticalization of the $3^{\text {rd }}$ person plural $k i$ ergative marker. They give the following example:

$$
\begin{array}{lll}
r i t z{ }^{\prime}, & x \text { - } \emptyset \text {-ki-chäp } & r \text {-oma' ri achin } \\
\text { DET dog } & \text { CMP-B3-PSV-grab } & \text { A3-RN DET man }
\end{array}
$$

'The dog is grabbed by the man.'

The authors point out that the above sentence has a singular direct argument and a singular oblique argument. $k i$, as a person marker, only refers to plural subjects of transitive sentences and therefore

${ }^{8}$ Dubois discusses this preference for intransitives as a means of foregrounding a human NP in his study of preferred argument structure (1987). 
cannot be referring to either the man or the dog. It appears that in such cases the generic 'they' has been used to such an extent that is has become bleached of its agent reference and has been grammaticalized as a passive marker.

In Chontal the availability of the periphrastic passive could allow the older morphological passive to become less important. If the periphrastic has a preference for implying an agent, the $k$ passive could be developing into a more impersonal passive. In almost all instances, this passive is translated into Spanish with the active voice with a generic third person:

'uy-ä'-b-int-e

A3-give-APL-PSV-INC

'To him it is given.'/ 'Le dan.'

k'os-b-int-i- $\varnothing$

bring-APL-PSV-CMP-B3

'It was brought.'/'Le trajeron.'

$$
\text { 'u-cher-k-an jop'o }
$$

A3-make-PSV-INC hat

'A hat is made'/'Se hace sombrero.'

Recall example (26) which Isaías translates as 'estuvo tirado', his use of the estar auxiliary in Spanish implies that this is a resultant participle; i.e. it cannot take an oblique agent phrase.

$$
\begin{array}{ll}
\text { 'ajn-i- } \emptyset & \text { chop-o } \\
\text { be-CMP-B3 } & \text { throw-ADJ }
\end{array}
$$

'It was thrown.'

The corresponding $x$-construction, however, is translated with ser:

$$
\begin{array}{ll}
x-i-\varnothing & \text { chop-o } \\
\text { go-CMP-B3 } & \text { throw-ADJ } \\
\text { 'It was thrown'/ 'Fue tirado.' }
\end{array}
$$

Sometimes both the morphological and periphrastic passive are translated with a ser construction:

$$
\begin{array}{ll}
x-i-\emptyset & b a j-a \\
\text { go-CMP-B3 } & \text { nail-ADJ } \\
\text { 'It was nailed.'/'Fue clavado.' } & \\
\text { ' } a & b a j-k-i-\emptyset \\
\text { PST } & \text { nail-PSV-CMP-B3 }
\end{array}
$$

'It was nailed.'/ 'Fue clavado.' 


$$
\begin{array}{lc}
x-i-\varnothing \quad \text { pop-o } \\
\text { go-CMP-B3 } & \text { roast-ADJ } \\
\text { 'It was roasted.'/‘Fue asado.' }
\end{array}
$$

As stated above, it is more common to use the generic third person active in Spanish to translate the Chontal morphological passive:

$$
\begin{aligned}
& \text { 'u-cher-b-int-e jop'o } \\
& \text { A3-make-APL-PSV-INC hat } \\
& \text { 'A hat is made'/ 'Le hacen sombrero.' }
\end{aligned}
$$

These translation choices support the claim that the morphological passive is prefered for agentless events. Another observation that seems to support this view is the frequent usage of a passive clause as a noun or an adjective where the agent is necessarily unimportant and, in fact, syntactically cumbersome to express:

$$
\begin{array}{llcl}
\text { ni ch'ok-o' } & \text { 'u-xoy-i- } \emptyset \text {-jo' } & n \text { - } u \text {-cher-b-int-e } & \text { 'u-jobäle } \\
\text { DET child-PL } & \text { A3-surround-CMP-B3-PL DET-A3-make-APL-PSV-INC } & \text { A3-party } \\
\text { 'The children surrounded the "she for whom is made her party (la festejada)".' } &
\end{array}
$$

In the above example the definite article indicates the entire clause has been turned into a noun; in the example below the masculine prefix 'aj-likewise indicates a nominalization:

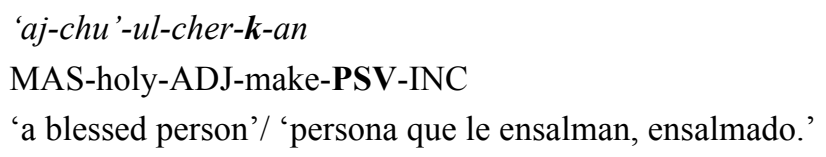

These observations, while not allowing us to establish a rule for the use of the different passives, do allow us to create a tentative hypothesis that can be further tested. As stated previously, most of the Mayan languages have an antipassive as well as a passive; they also have a distinction between an absolute passive where the demoted agent is not mentioned and a passive where the demoted agent is still present. Kaufman \& Norman state that "Mayan languages typically have several different ways of forming passives; these are distinguished according to the type of transitive stem involved, whether or not the agent of the action may be expressed, whether the action of the verb is marked as being successful, possible, or sudden, as well as according to other features" (1984:108). If Chontal has no antipassive and only one passive ( $k$ for root and int for derived), the periphrastic passive, while overlapping functionally in many ways with the other construction, could be filling an expressive need. Hopper \& Traugott state that this coexistence of competing forms is typical as "newly innovated forms compete with older ones because they are felt to be more expressive than what was previously available before. This competition allows, even encourages the recession or loss of older forms. Textual evidence provides strong support for this view of coexisting competing forms and constructions, rather than a cycle of loss and renewal." (1990:123). During this period of co-existence the 'competing' forms could develop pragmatic differences. If a functional difference is evolving, however, it is probably unstable and/or varies according to the speaker. In other words, the different functions I am proposing are probably tendencies or preferences rather than rules. 
Given these caveats, we can hypothesize that the occurrence of the periphrastic passive is not random. The clues to its usage are based on 1) its usage with an oblique agent and, 2) its translation into Spanish. Isaías is fairly consistent with the way he translates the different passives; for the morphological passive he almost always uses an active third person plural translation. Based on these observations, the following is a tentative description of the various functions of the passives and passive-like constructions in Chontal:

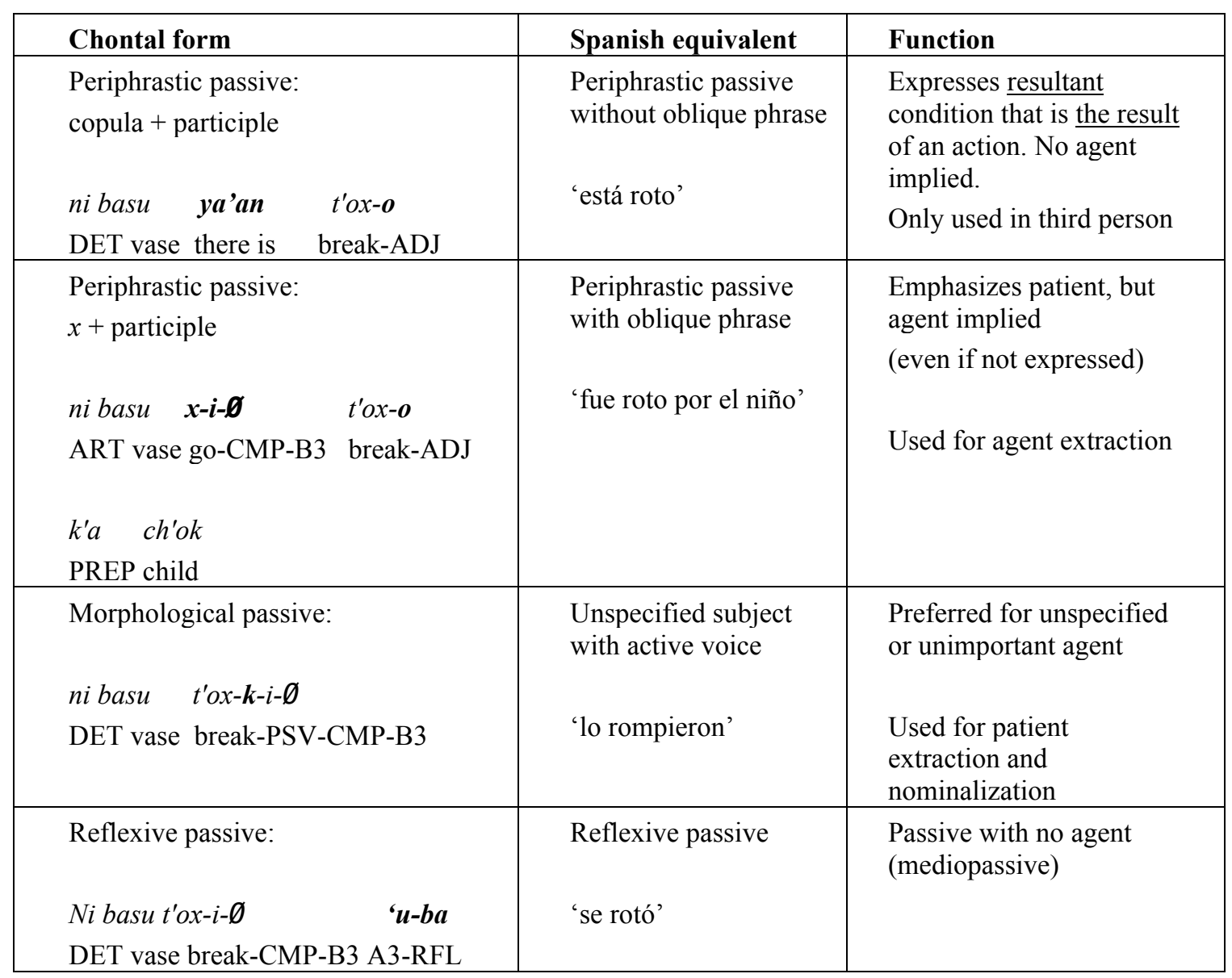

\section{Conclusion and Directions for further research}

Speakers of Chontal have a wide variety of transitivity reducing-constructions available to them, ranging from stative constructions based on participles, periphrastic constructions utilizing auxiliary verbs, and morphological passives. The Chontal periphrastic passive appears to be a calque of the Spanish ser+ past participle. I have presented four reasons for this: 1) the lack of any similar passive in the other Mayan languages, 2) the typological rarity of the auxiliary+ past participle passive construction (and corresponding preference for a morphological passive) 3) the homophony between the past tense of Spanish ser and ir provides a good template for Chontal 'to go' and, 4) the fact that the functional distribution of the Chontal periphrastic passive appears to mirror the functional distribution of the Spanish model. This last claim is still tentative and needs further field work data to better support it; to test it I would need a larger amount of data in a discourse context. Because the passive is a discourse-driven construction, any isolated examples run the risk of being unnatural. It is particularly difficult to tell if the oblique phrase is mandatory or optional in isolated contexts. We also need to take into account sociolinguistic factors. Isaías is a bilingual writer who 
has travelled more extensively than most other Chontales. It would be interesting to see how widespread the periphrastic passive is and what variables figure into its use: age, level of education and, in particular, relationship with the Spanish language. Understanding the interaction of these factors would give us a better understanding of the diffusibilty of passives in general as well as special mechanisms, such as replication, that may drive this process of auxiliation.

\section{References}

Aikhenvald, Alexandra \& Robert M. W. Dixon. 2002. Grammars in contact: A cross-linguistic typology. Oxford: Oxford University Press.

Aissen, Judith L. 1990. Una teoría de voz para idiomas Mayas. In: Lecturas sobre la lingüistica maya. Nora England \& Stephen R. Elliott (eds.), 399-419. Guatemala: Centro de Investigaciones Regionales de Mesoamérica.

Benveniste, Emile. 1968. Mutations of linguistic categories. In: Winfred P. Lehmann \& Yakov Malkiel (eds.), 83-94. Directions for Historical Linguistics: A Symposium. Austin: University of Texas Press.

Blake, Barry J. 2001. Global trends in language. Linguistics 39:1009-28.

Broadwell, George Aaron \& Lachlan Duncan. 2002. A new passive in Kaqchikel. Linguistic Discovery 1-2:26-43.

Bruyne, Jacques de. 1996. A comprehensive Spanish Grammar. London: Blackwell Publishing.

Dayley, Jon P. 1990. Voz y ergatividad en idiomas Mayas. In: Nora England \& Stephen R. Elliott (eds.), 335-398. Lecturas sobre la lingüistica maya Guatemala. Centro de Investigaciones Regionales de Mesoamérica.

Du Bois, John. 1987. The discourse basis of ergativity. Language 63-4:805-855.

England, Nora. 2001. Introducción a la grammática de los idiomas mayas. Guatemala: Ch'olsamaj.

Harris, Alice, \& Lyle Campbell. 1995. Historical syntax in cross-linguistic perspective. Cambridge: Cambridge University Press.

Haspelmath, Martin. 1990. The grammaticization of passive morphology. Studies in Language 14$1: 25-72$.

Hernández Isidro, Isaías. 1997. Las doce verdades. cha’jp'e t’ok chap'e älkan. Dirección general de culturas populares. México, D.F.

Heine, Bernd, \& Tania Kuteva. 2002. World lexicon of grammaticalization. Cambridge: Cambridge University Press

Kaufman, Terrence. 1990. Algunos rasgos estructurales de los idiomas Mayances. In: Nora England \& Stephen R. Elliot (eds.), 59-114. Lecturas sobre la lingüística Maya. La Antigua, Guatemala: Centro de Investigaciones Regionales de Mesoamérica.

Kaufman, Terrence \& William Norman. 1984. An outline of proto-Cholan phonology, morphology, and vocabulary. In: John S. Justeson \& Lyle Campbell (eds.), 77-166. Phoneticism in Maya hieroglyphic writing. Institute of Mesoamerican Studies, Pub. No. 9. Albany: SUNYAlbany.

Keller, Kathryn C. \& Plácido Luciano G. 1997. Diccionario Chontal de Tabasco. Tucson, AZ: Summer Institute of Linguistics. 
Knowles-Berry, Susan M. 1984. A descriptive grammar of Chontal Maya (San Carlos dialect). PhD dissertation: Tulane University.

Kuteva, Tania. 2001. Auxiliation. London: Oxford University Press.

Li, Charles N. \& Sandra A. Thompson. 1981. Mandarin Chinese, a functional reference grammar. Berkeley - Los Angeles-London: University of California Press.

Rodriguez, Jose Obispo \& Matzar, Pedro. 1997. Rukemik ri Kaqchikel chi.' Guatemala: Cholsamaj.

Pérez, Eduardo \& Jiménez, Odilio. 1997. Ttxoolil Qyool Mam - Gramática Mam. Guatemala: Cholsamaj.

Siewierska, Anna. 1984. The passive: A comparative analysis. Kent: Croom Helm. 